\title{
The Effect of Environmental Conditions on Electrochemical Corrosion Behavior of AISI 1018 Low-carbon Steel in Concrete Pore Solution
}

\author{
Ming $L i$ \\ School of civil engineering, Jilin Jianzhu University, Changchun Jilin 130118, China \\ E-mail:minglipossess@ sina.com
}

doi: $10.20964 / 2021.08 .19$

Received: 31 March 2021/ Accepted: 17 May 2021 / Published: 30 June 2021

The effect of environmental conditions such as dissolved oxygen (DO) and temperature on electrochemical corrosion behavior of AISI 1018 low-carbon steel in concrete pore solution (CPS) were investigated. The corrosion behavior of low-carbon steel was determined using electrochemical impedance spectroscopy (EIS) and potentiodynamic polarization methods at temperatures ranging from 20 to $40^{\circ} \mathrm{C}$ and DOES concentration from $0.5 \mathrm{ppm}$ to $4.5 \mathrm{ppm}$. The corrosion rate of steels increased with increasing ambient temperatures. The electrochemical corrosion resistance was observed to be higher in CPS with lower DO concentrations. The SEM analysis shows that the metal dissolution rate was more intense in CPS with higher DO levels.

Keywords: Dissolved oxygen; Electrochemical corrosion behavior; AISI 1018 low-carbon steel; Cement pore solution

\section{$\underline{\text { FULL TEXT }}$}

(C) 2021 The Authors. Published by ESG (www.electrochemsci.org). This article is an open access article distributed under the terms and conditions of the Creative Commons Attribution license (http://creativecommons.org/licenses/by/4.0/). 